\title{
Effects of Caffeine Treatment on Hepatopulmonary Syndrome in Biliary Cirrhotic Rats
}

\author{
Ching-Chih Chang 1,2,3, Chiao-Lin Chuang 1,2, Ming-Hung Tsai ${ }^{4}$, I.-Fang Hsin ${ }^{2,3}$, \\ Shao-Jung Hsu ${ }^{2,3}$, Hui-Chun Huang ${ }^{1,2,3, *,+}$, Fa-Yauh Lee ${ }^{2,3, *,+}$ and Shou-Dong Lee ${ }^{2,5}$ \\ 1 Division of General Medicine, Department of Medicine, Taipei Veterans General Hospital, Taipei 112, \\ Taiwan; ccchang7@vghtpe.gov.tw (C.-C.C.); clchuang@vghtpe.gov.tw (C.-L.C.) \\ 2 Faculty of Medicine, National Yang-Ming University School of Medicine, Taipei 112, Taiwan; \\ yfhsin@vghtpe.gov.tw (I.-F.H.); sjhsu@vghtpe.gov.tw (S.-J.H.); sdlee@vghtpe.gov.tw (S.-D.L.) \\ 3 Division of Gastroenterology and Hepatology, Department of Medicine, Taipei Veterans General Hospital, \\ Taipei 112, Taiwan \\ 4 Chang Gung University College of Medicine and Division of Gastroenterology and Hepatology, Chang \\ Gung Memorial Hospital, Taoyuan 333, Taiwan; mhtsai@adm.cgmh.org.tw \\ 5 Division of Gastroenterology, Department of Medicine, Cheng Hsin General Hospital, Taipei 112, Taiwan \\ * Correspondence: hchuang2@vghtpe.gov.tw (H.-C.H.); fylee@vghtpe.gov.tw (F.-Y.L.); \\ Tel.: +886-2-2875-7769 (H.-C.H.); +886-2-2875-7147 (F.-Y.L.); \\ Fax: +886-2-2875-7809 (H.-C.H.); +886-2-2875-7809 (F.-Y.L.) \\ + These authors contributed equally to this work.
}

Received: 2 March 2019; Accepted: 25 March 2019; Published: 28 March 2019

\begin{abstract}
Hepatopulmonary syndrome (HPS) is a lethal complication of cirrhosis characterized by hypoxia and overt intrapulmonary shunting. In this study, we investigated the effect of caffeine in rats with common bile duct ligation (CBDL)-induced liver cirrhosis and HPS. CBDL rats were randomly allocated to receive caffeine or vehicle for 14 days. On the 28th day after CBDL, mortality rate, hemodynamics, liver, and renal biochemistry parameters and arterial blood gas analysis were evaluated. Lung and liver were dissected for the evaluation of inflammation, angiogenesis and protein expressions. In another series with parallel groups, the intrapulmonary shunting was determined. Caffeine significantly reduced portal pressure (caffeine vs. control: $10.0 \pm 3.7$ vs. $17.0 \pm 8.1 \mathrm{mmHg}$, $p<0.05)$ in CBDL rats. The mortality rate, mean arterial pressure, biochemistry data and hypoxia were similar between caffeine-treated and control groups. Caffeine alleviated liver fibrosis and intrahepatic angiogenesis but intrapulmonary inflammation and angiogenesis were not ameliorated. The hepatic VEGF/ Rho-A protein expressions were down-regulated but the pulmonary inflammationand angiogenesis-related protein expressions were not significantly altered by caffeine. Caffeine did not reduce the intrapulmonary shunting, either. Caffeine has been shown to significantly improve liver fibrosis, intrahepatic angiogenesis and portal hypertension in cirrhotic rats, however, it does not ameliorate HPS.
\end{abstract}

Keywords: caffeine; hepatopulmonary syndrome; liver cirrhosis

\section{Introduction}

Coffee, a worldwide consumed beverage, has caught attention for its potential benefits in liver diseases [1]. Increased coffee consumption is associated with the reduction of liver fibrosis in patients with chronic liver disease and the incidence of hepatocellular carcinoma [2,3]. Caffeine (3,7-dihydro-1,3,7-trimethyl-1H-purine-2,6-dione) is the major compound in coffee and many energy drinks. The anti-angiogenesis effect of caffeine has been noticed [4]. In addition, the anti-inflammatory effects of caffeine have been reported in rats challenged with lipopolysaccharide [5]. In our previous 
study, we found that caffeine reduced portal pressure and ameliorated portal-systemic shunting, mesenteric angiogenesis, and liver fibrosis in cirrhotic rats [6].

Hepatopulmonary syndrome (HPS) is characterized by hypoxia in patients with chronic liver diseases, especially in those with cirrhosis [7]. Emerging data show that the prevalence of HPS ranges from 5 to $32 \%$ in cirrhotic patients who need liver transplantation [8]. The prognosis of HPS is ominous, evidenced by a median survival of 24 months and a five-year survival rate of $23 \%$ in cirrhotic patients developing HPS [9]. HPS is characterized by overt intrapulmonary shunting due to vasodilatation and abnormal angiogenesis $[10,11]$. Intrapulmonary shunting is the main condition causing arterial hypoxia in HPS [12]: Unoxygenated blood can escape through the pulmonary shunting directly into the systemic circulation without gas exchange. The severity of arterial hypoxemia is related to the extent of ventilation-perfusion mismatch, intrapulmonary shunting and diffusion impairment [13]. Abnormal pulmonary angiogenesis plays a crucial role in the development and maintenance of HPS. Zhang et al. reported that pathological pulmonary angiogenesis and enhancement of vascular endothelial growth factor (VEGF) production by intrapulmonary monocytes were associated with the development of HPS in experimental animals [10]. Our previous study also showed that sorafenib alleviated experimental HPS by attenuating intrapulmonary angiogenesis through down-regulating the VEGF/VEGF-receptor 2 pathway [14]. In addition to abnormal angiogenesis, the initiation of HPS comes from overwhelming intrapulmonary inflammation. The chemokine fractalkine $\left(\mathrm{CX}_{3} \mathrm{CL}_{1}\right)$ expression and signaling are increased in HPS rats, which contributes to pulmonary intravascular monocyte accumulation, angiogenesis and the development of experimental HPS [15]. Moreover, Thenappan et al. found that experimental HPS resulted from the intrapulmonary accumulation of CD68-positive macrophages, and the depletion of macrophages might exert a therapeutic potential [16]. Consistent with those findings, we previously reported that rosuvastatin alleviated experimental HPS through the inhibition of pulmonary inflammatory angiogenesis, which was related to the down-regulation of the tumor necrosis factor- $\alpha(\mathrm{TNF}-\alpha)$ /nuclear factor kappa B (NFKB) and VEGF/Rho-A pathways [17].

The common bile duct ligation (CBDL) murine model is an established animal model of liver cirrhosis and HPS [10,14-17]. Targeting the mechanism of HPS involving abnormal intrapulmonary angiogenesis and inflammation, in this study, we aimed to investigate the effects of caffeine on HPS in rats with CBDL-induced liver cirrhosis and the underlying mechanisms.

\section{Results}

\subsection{Mortality Rates of Caffeine- and Vehicle-Treated CBDL Rats}

There was no significant difference in mortality rates between caffeine- and vehicle-treated (control) CBDL rats (control vs. caffeine: $25 \%(3 / 12)$ vs. $33.3 \%(4 / 12), p>0.05)$.

\subsection{Hemodynamics, Biochemistry Parameters and Blood Gas Analysis}

Table 1 displays body weight, hemodynamic change, liver and renal biochemistry parameters of control $(n=9)$ and caffeine-treated $(n=8)$ CBDL rats. In our previous report [17], CBDL rats had significantly higher portal pressure, elevated total bilirubin (TB), aspartate aminotransferase (AST), alanine aminotransferase (ALT), decreased partial pressure of oxygen $\left(\mathrm{PaO}_{2}\right)$ and increased alveolar-arterial oxygen gradient $\left(\mathrm{AaPO}_{2}\right)$ compared to the sham-operated rats, indicating the typical presentation of liver cirrhosis and HPS (see Supplementary Table S1). In the present study, body weight and heart rate were not significantly different between the caffeine-treated and control CBDL rats. Caffeine significantly decreased portal pressure (control vs. caffeine: $17.0 \pm 8.1 \mathrm{vs.} 10.0 \pm 3.7 \mathrm{mmHg}$, $p<0.05)$. The plasma levels of creatinine, TB, AST, ALT were not significantly influenced by caffeine. The $\mathrm{PaO}_{2}$, partial pressure of carbon dioxide $\left(\mathrm{PaCO}_{2}\right)$ and $\mathrm{AaPO}_{2}$ in the arterial blood gas analysis were not significantly different either. 
Table 1. Body weight, hemodynamics, biochemistry and arterial blood gas data in cirrhotic rats treated with or without caffeine.

\begin{tabular}{ccc}
\hline & $\begin{array}{c}\text { Control } \\
(\boldsymbol{n}=\mathbf{9})\end{array}$ & $\begin{array}{c}\text { Caffeine } \\
(\boldsymbol{n}=\mathbf{8})\end{array}$ \\
\hline $\mathrm{BW}(\mathrm{g})$ & $357 \pm 54$ & $330 \pm 35$ \\
$\mathrm{MAP}(\mathrm{mmHg})$ & $134 \pm 17$ & $133 \pm 27$ \\
$\mathrm{PP}(\mathrm{mmHg})$ & $17.0 \pm 8.1$ & $10.0 \pm 3.7^{*}$ \\
$\mathrm{AST}(\mathrm{IU} / \mathrm{L})$ & $625 \pm 114$ & $721 \pm 78$ \\
$\mathrm{ALT}(\mathrm{IU} / \mathrm{L})$ & $216 \pm 142$ & $183 \pm 55$ \\
$\mathrm{~TB}(\mathrm{mg} / \mathrm{dL})$ & $7.9 \pm 2.3$ & $7.7 \pm 0.5$ \\
$\mathrm{Creatinine} \mathrm{(mg/dL)}$ & $0.5 \pm 0.2$ & $0.4 \pm 0.1$ \\
$\mathrm{PaO}_{2}(\mathrm{mmHg})$ & $75.1 \pm 10.2$ & $78.6 \pm 6.5$ \\
$\mathrm{PaCO}_{2}(\mathrm{mmHg})$ & $37.4 \pm 5.3$ & $39.8 \pm 5.7$ \\
$\mathrm{AaPO}_{2}(\mathrm{mmHg})$ & $28.1 \pm 7.0$ & $21.7 \pm 9.1$ \\
\hline
\end{tabular}

BW: body weight; MAP: mean arterial pressure; PP: portal pressure; AST: aspartate aminotransferase; ALT: alanine aminotransferase; TB: total bilirubin, $\mathrm{Cr}$ : creatinine; $\mathrm{PaO}_{2}$ : partial pressure of oxygen; $\mathrm{PaCO}_{2}$ : partial pressure of carbon dioxide; $\mathrm{AaPO}_{2}$ : alveolar-arterial oxygen gradient; ${ }^{*} p<0.05$ compared to control group.

\subsection{Histopathological Change and Immunochemical Staining of Liver}

The hepatic hematoxylin and eosin (H\&E) staining of CBDL rats showed mononuclear cells infiltration, ballooning change of hepatocytes and destruction of the lobular structure, indicating the inflammatory change of the livers. Sirius red staining revealed the obvious fibrosis of the livers (stained in red), which was significantly attenuated by caffeine. The livers of the control CBDL rats had many CD31-positive staining cells (brown color), which was also attenuated by caffeine (Figure 1A).

A

\section{Caffeine}

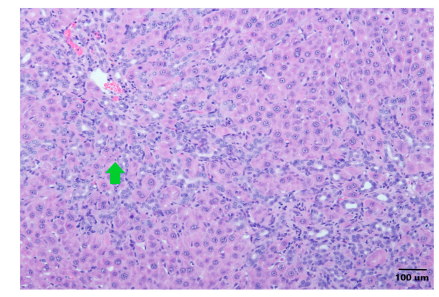

\section{H\&E stain}
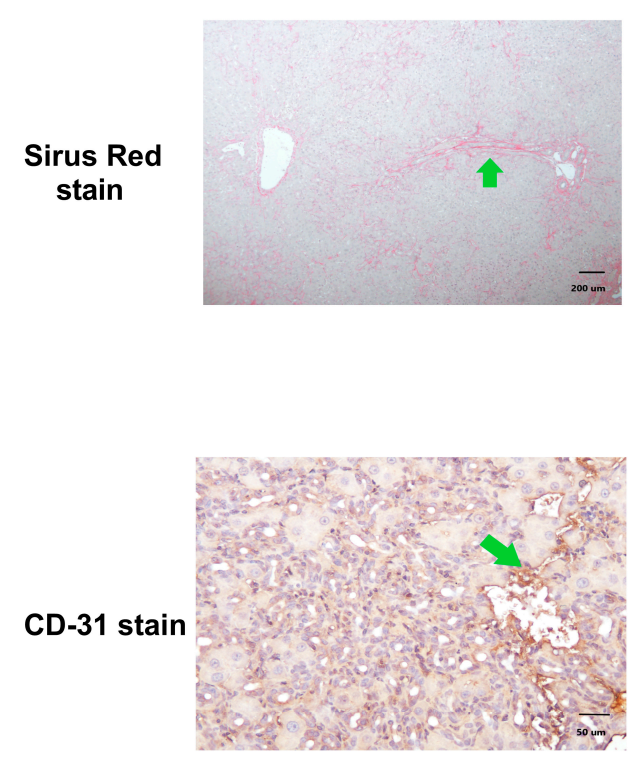

Control
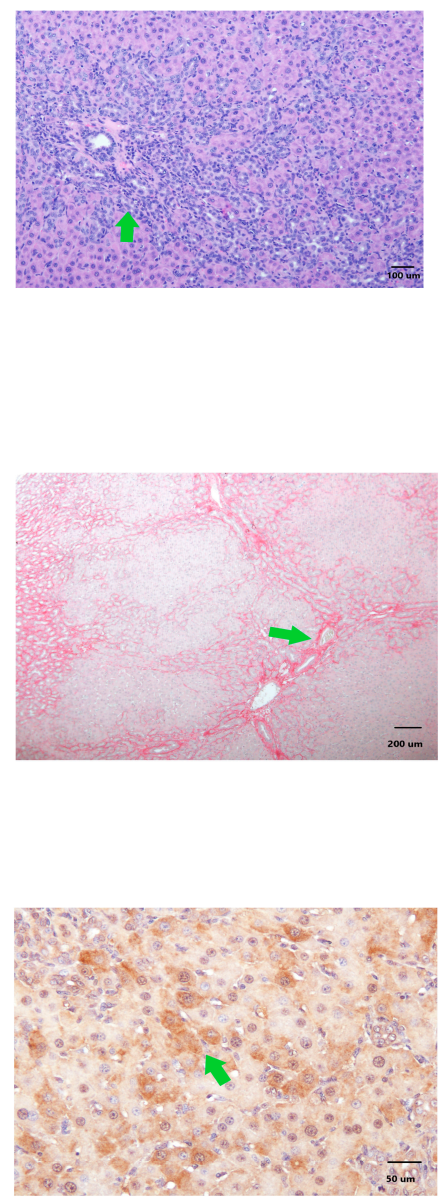

Figure 1. Cont. 
B
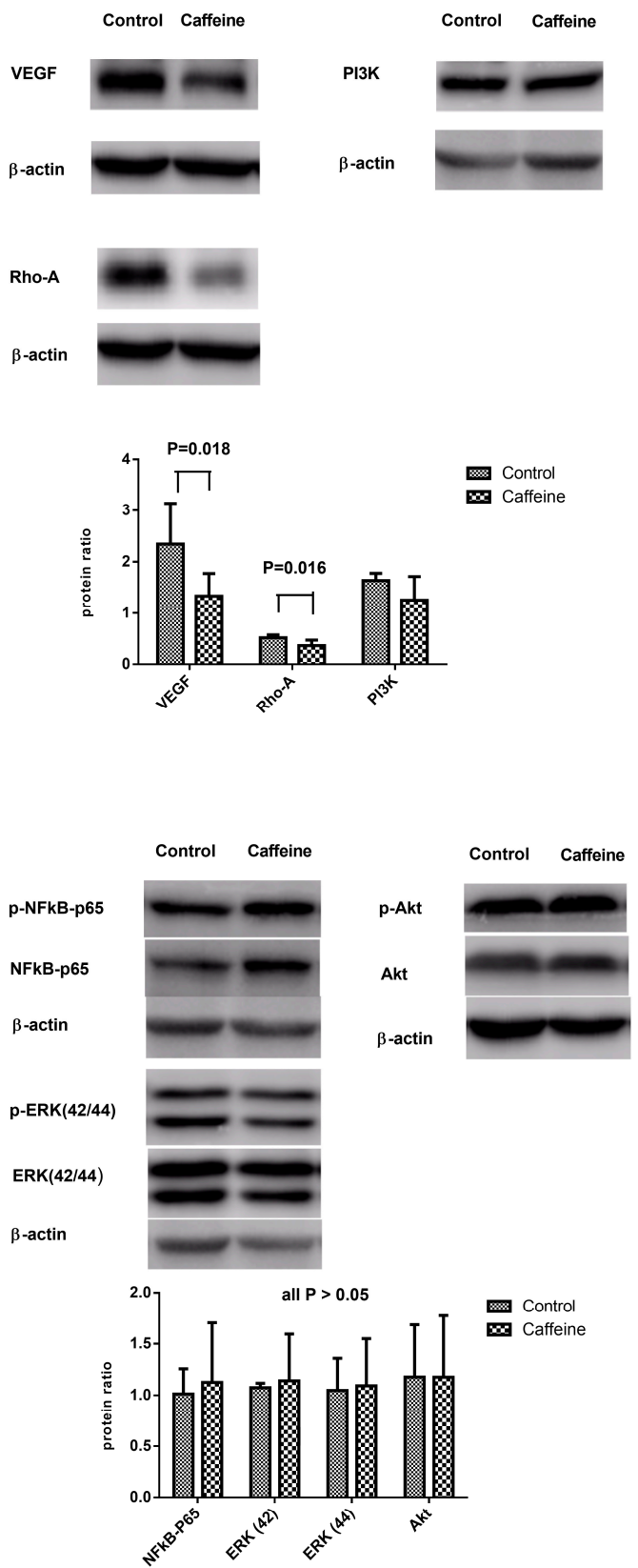

Figure 1. (A) Liver histology and immunochemical staining of common bile duct ligation (CBDL) rats treated by caffeine or distilled water (control). The representative hematoxylin and eosin (H\&E) staining image of control CBDL rats shows ballooning change of hepatocytes accompanied by many inflammatory cells (green arrow), indicating the inflammatory change of liver (magnification 100x, upper panel). Liver fibrosis is demonstrated by Sirius red staining (magnification 40x, green arrow indicating red area, middle panel). As compared with the control group, caffeine significantly attenuates liver fibrosis (middle panel). In addition, many CD31-positive staining cells (green arrow indicating brown cells) are noted in the control group, which is attenuated by caffeine (magnification 200x, lower panel). (B) Hepatic protein expressions of caffeine-treated and control CBDL rats. The densitometric quantification and representative Western blots of VEGF and Rho-A kinase, but not $\mathrm{PI}_{3} \mathrm{~K}$, protein expressions are significantly down-regulated by caffeine treatment (VEGF, $p=0.018$, Rho-A kinase, $p=0.016$, upper panel). The phosphorylated-NF- $\kappa B$ p65, phosphorylated-ERK $(42 / 44)$, and phosphorylated-Akt protein expressions are not significantly influenced by caffeine (all $p>0.05$; lower panel). The representative Western blots are shown. 


\subsection{Hepatic Protein Expressions}

Figure $1 B$ reveals hepatic protein expressions of CBDL rats treated by vehicle $(n=5)$ or caffeine $(n=7)$. VEGF and Rho-A kinase expressions were significantly attenuated by caffeine treatment (control vs. caffeine: VEGF $/ \beta$-actin $=2.34 \pm 0.79$ vs. $1.34 \pm 0.44, p=0.018$; Rho-A $/ \beta$-actin $=0.52 \pm 0.06$ vs. $0.37 \pm 0.11, p=0.016$; Figure $1 \mathrm{~B})$. The phosphoinositide 3-kinases $\left(\mathrm{PI}_{3} \mathrm{~K}\right)$, phosphorylated- NF- $\mathrm{B}$ p 65, phosphorylated-extracellular signal-regulated kinase (ERK) 42/44, and phosphorylated-Akt protein expressions were not significantly influenced by caffeine $\left(\mathrm{PI}_{3} \mathrm{~K} / \beta\right.$-actin

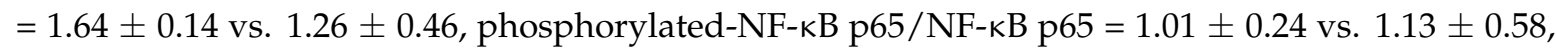
phosphorylated-ERK(42)/ERK $(42)=1.07 \pm 0.04$ vs. $1.14 \pm 0.45$, phosphorylated-ERK $(44) / \operatorname{ERK}(44)=$ $1.05 \pm 0.31$ vs. $1.09 \pm 0.46$, phosphorylated-Akt/Akt $=1.18 \pm 0.51$ vs. $1.18 \pm 0.60 ;$ all $p>0.05)$.

\subsection{Pulmonary Inflammation and Angiogenesis}

There were many polymorphonuclear cells in the lungs, accompanied by alveolar wall thickening in both caffeine- and vehicle-treated CBDL rats. The CD68-positive staining macrophage (stained in brown) infiltration was not significantly attenuated by caffeine. The numbers of von Willebrand factor (vWF)-staining cells (stained in brown) were not significantly different between control and caffeine-treated CBDL rats (Figure 2A).

A

Caffeine

H\&E stain

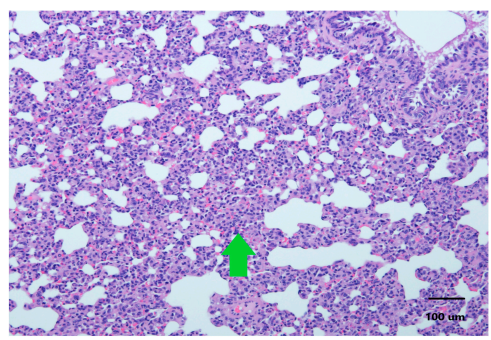

Control
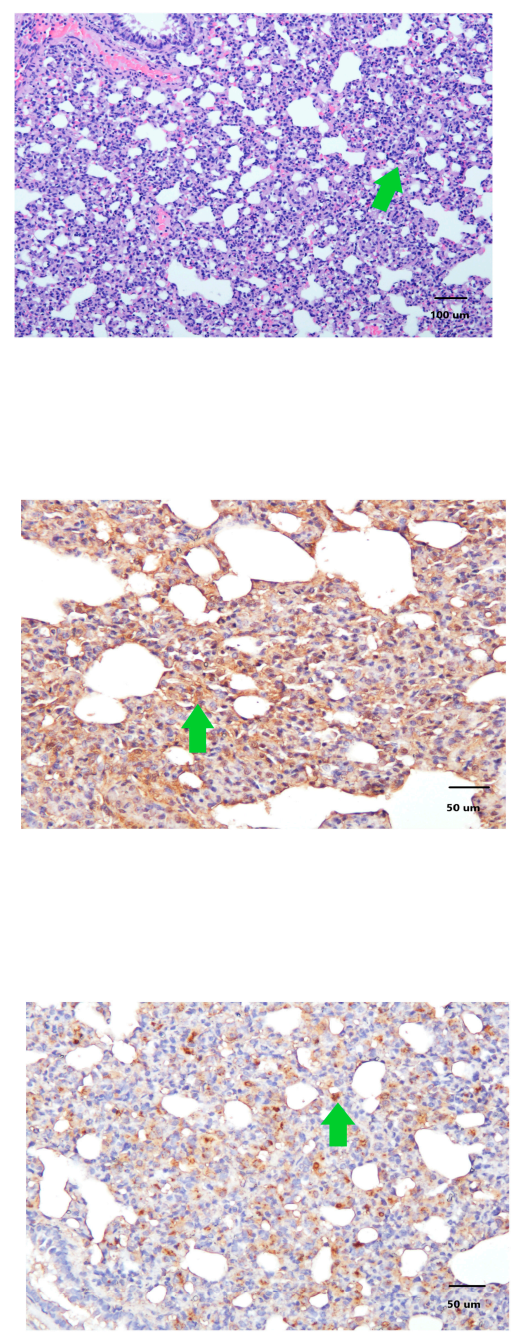

CD-68 stain

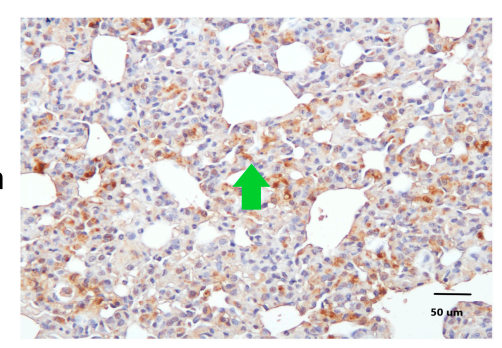

Figure 2. Cont. 


\section{B}
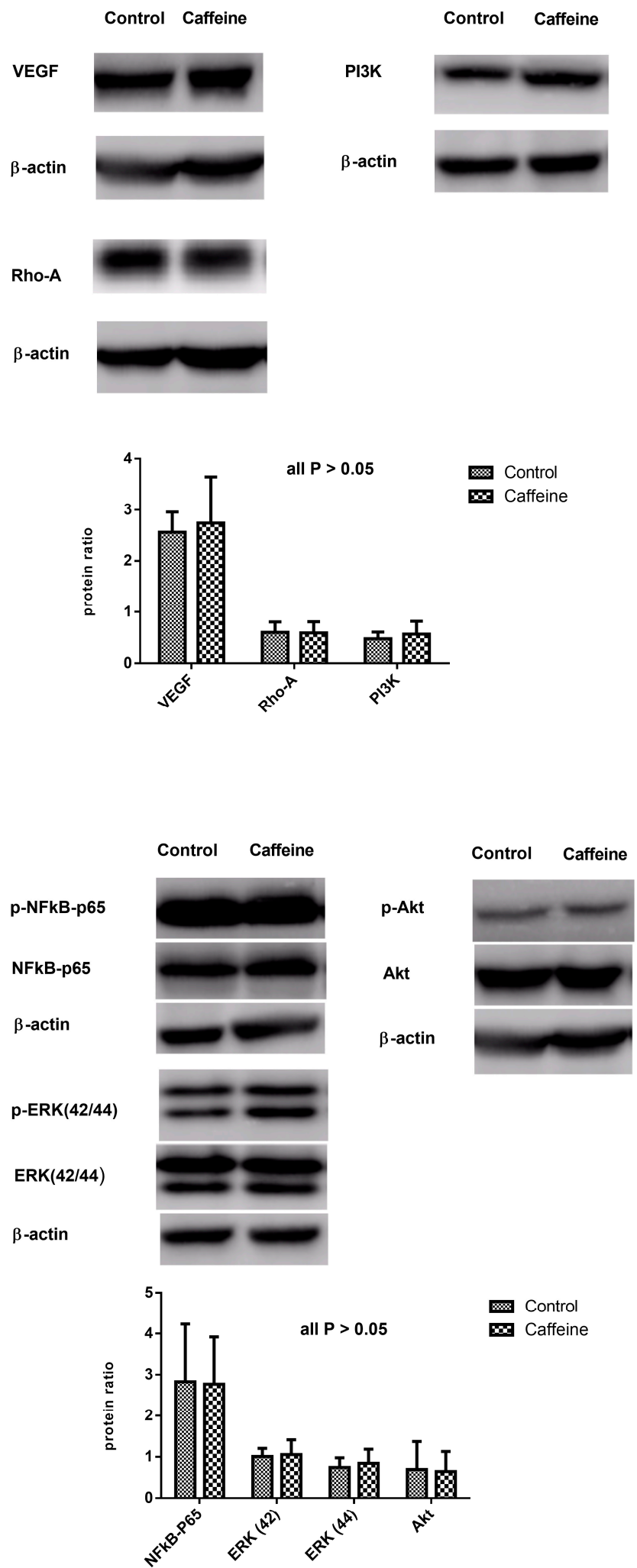

Figure 2. Cont. 


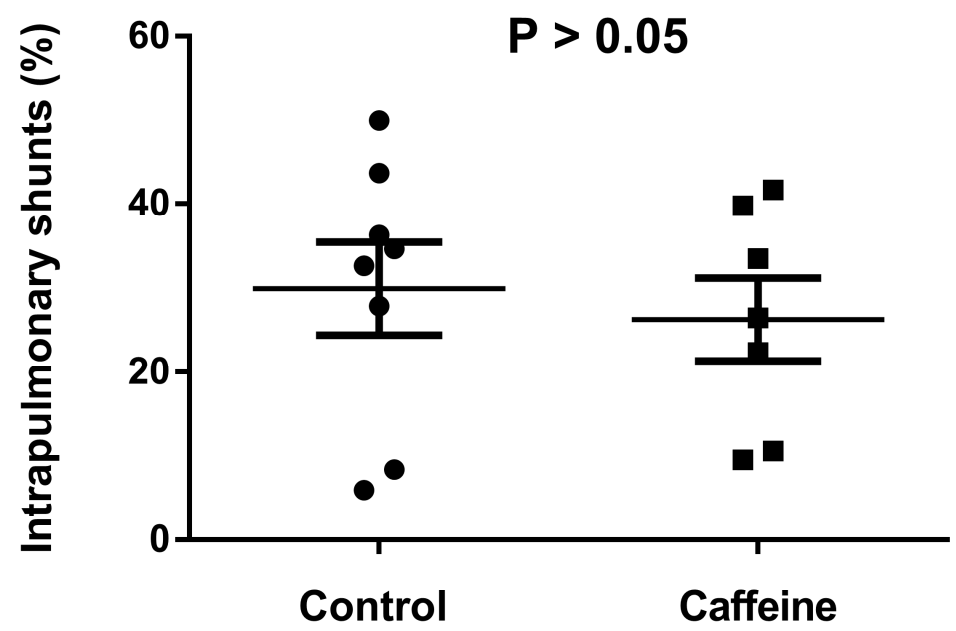

Figure 2. (A) Pulmonary histology and immunochemical staining of CBDL rats treated by caffeine or distilled water. The representative H\&E staining image depicts prominent polymorphonuclear cells infiltration (green arrow) in control and caffeine-treated rats (magnification 100x, upper panel). Caffeine does not diminish vWF-positive staining cells (green arrow indicating brown cell; magnification 200x, middle panel) as compared to the control rats. Also, the CD68-positive staining cells are not attenuated by caffeine (green arrow indicating brown cell; magnification 200x, lower panel). (B) Pulmonary protein expressions of caffeine-treated and control CBDL rats. The densitometric quantification and representative Western blots of VEGF, Rho-A kinase and $\mathrm{PI}_{3} \mathrm{~K}$ are similar between caffeine-treated and control groups (upper panel). The phosphorylated-NF-kB p65, phosphorylated-ERK(42/44), and phosphorylated-Akt protein expressions are not significantly influenced by caffeine (lower panel). The representative Western blots are shown. (C) Degrees of pulmonary shunting in caffeine-treated and control CBDL rats. The shunting degrees are similar between the two groups $(p>0.05)$.

\subsection{Protein Expressions in the Lungs of CBDL Rats Treated by Vehicle $(n=5)$ or Caffeine $(n=7)$}

Figure $2 \mathrm{~B}$ shows the pulmonary protein expressions of $\mathrm{CBDL}$ rats treated by vehicle or caffeine. The VEGF, Rho-A kinase, $\mathrm{PI}_{3} \mathrm{~K}$, phosphorylated-NF- $\mathrm{KB}$ p65, phosphorylated-ERK $(42 / 44)$, and phosphorylated-Akt protein expressions were not significantly different between caffeine-treated and control rats $(\mathrm{VEGF} / \beta$-actin $=2.56 \pm 0.39$ vs. $2.74 \pm 0.90$, Rho-A $/ \beta$-actin $=0.60 \pm 0.20$ vs. $0.59 \pm 0.22, \mathrm{PI}_{3} \mathrm{~K} / \beta$-actin $=0.50 \pm 0.13$ vs. $0.57 \pm 0.25$, phosphorylated-NF- $\mathrm{kB}$ p65/NF- $\mathrm{kB}$ p65 $=2.83 \pm 1.40$ vs. $2.77 \pm 1.14$, phosphorylated-ERK(42)/ERK(42) $=1.01 \pm 0.20$ vs. $1.06 \pm 0.36$, phosphorylated-ERK $(44) / E R K(44)=0.74 \pm 0.23$ vs. $0.84 \pm 0.34$, phosphorylated-Akt $/$ Akt $=0.69 \pm$ 0.68 vs. $0.64 \pm 0.49$, all $p>0.05)$.

\subsection{Intrapulmonary Shunting}

Figure $2 \mathrm{C}$ reveals intrapulmonary shunting of CBDL rats treated by vehicle $(n=8)$ or caffeine $(n=7)$. The shunting was not significantly different between these two groups (control vs. caffeine: $29.9 \pm 15.6$ vs. $26.3 \pm 13.0 \% ; p>0.05)$.

\section{Discussion}

We had previously reported that both prophylactic caffeine treatment (started from the first day of CBDL) and therapeutic caffeine treatment (started from the 14th day post-CBDL) ameliorated liver fibrosis and portal hypertension [6]. Consistent with those findings, the current study also found that therapeutic caffeine treatment with the same dose for two weeks ameliorated liver fibrosis, alleviated 
intrahepatic angiogenesis and reduced portal pressure in rats with CBDL-induced cirrhosis. The mean arterial pressure was not significantly altered by caffeine, implicating that caffeine did not exert adverse effects on systemic hemodynamics. Although caffeine ameliorated liver injury as evidenced by decreased ALT, AST and TB levels in rats with thioacetamide- or carbon tetrachloride-induced liver damage [18,19], our present and previous studies [6] show that the plasma levels of ALT, AST and TB were not influenced by caffeine in CBDL rats. This might be ascribed to the severe and relatively non-modifiable bile stasis and inflammation induced by common bile duct ligation and section in CBDL model. Nevertheless, caffeine still ameliorated the liver fibrosis and portal hypertension in CBDL rats with biliary cirrhosis. The anti-inflammatory impact of caffeine on various types of liver damage, indeed, awaits further investigation. On the other hand, the intrapulmonary inflammation and angiogenesis were not reversed by caffeine. The hypoxia and intrapulmonary shunting were not ameliorated either. These findings suggest that caffeine, although capable of alleviating portal hypertension and liver fibrosis, is not able to mitigate HPS in CBDL rats.

Caffeine is an adenosine $A_{1}$ and $A_{2 A}$ receptor antagonist [20]. Adenosine is a potent endogenous regulator of inflammation and tissue repair. Chan et al. showed that caffeine reversed hepatic fibrosis through inhibition of adenosine receptors in cirrhotic mice [21]. In the present study, we found that caffeine significantly ameliorated liver fibrosis and reduced portal pressure in cirrhotic rats, supporting the benefit of using caffeine treatment in cirrhotic patients.

Emerging evidence shows that the elevated adenosine level observed in ischemic tissue contributes to hypoxia-induced angiogenesis [22]. Extracellular adenosine activates $A_{2 A}$ receptors, which stimulates the release of VEGF from the parenchymal cells, followed by endothelial cells proliferation and migration [23]. Through antagonizing the adenosine receptors, caffeine attenuates angiogenesis. In the current study, we demonstrated that caffeine reduced the extent of hepatic CD31-positive staining cells, indicating the attenuation of intrahepatic angiogenesis. Furthermore, caffeine attenuated the hepatic VEGF/Rho-A kinase protein expressions, which are important mediators modulating angiogenesis. Accordingly, our findings suggest that caffeine ameliorates abnormal intrahepatic angiogenesis through, at least in part, inhibition of VEGF/Rho-A kinase pathway. Nevertheless, caffeine did not reduce intrapulmonary vWF-positive staining cells and pulmonary VEGF protein expression. In addition, the intrapulmonary shunts were not influenced by caffeine. According to the discrepant results from lungs and livers, our data indicate that caffeine-related anti-angiogenesis effect is organ-specific in cirrhosis.

In addition to anti-angiogenesis effects, caffeine has been reported to exert beneficial effects on pulmonary inflammation as well as airway remodeling [24]. In a large US cohort study, the inverse association of coffee consumption was observed for deaths from heart disease, chronic respiratory diseases, diabetes, pneumonia and influenza [25]. The researchers postulated that coffee may reduce mortality risk by affecting inflammation, lung function, insulin sensitivity, and depression. The anti-inflammatory effect of caffeine varies with treatment protocols and doses [26]. Li et al. found that chronic caffeine treatment for two weeks or acute high doses $(50 \mathrm{mg} / \mathrm{kg}$, $30 \mathrm{~min}$ before acute lung injury) significantly attenuated lung edema, hemorrhage, neutrophil recruitment and the inflammatory cytokine expression in mice with acute lung injury. In contrast, acute caffeine treatment at relatively low doses $(5,15,30 \mathrm{mg} / \mathrm{kg})$ enhanced pulmonary inflammation and damage [26]. However, the present study applying high doses of caffeine $(50 \mathrm{mg} / \mathrm{kg})$ to cirrhotic rats showed that the pulmonary polymorphonuclear cells and CD68-positive staining macrophages were not attenuated, indicating a lack of therapeutic effect on pulmonary inflammation in cirrhosis. Since CD68-positive staining macrophages participate actively in initiating pulmonary inflammation and developing HPS $[16,17,27]$, this might be a crucial factor responsible for the failure of caffeine to treat HPS.

The coffee or caffeine consumption has many other effects on the liver and lung. We summarize these emerging findings in the Table $2[6,28-41]$ and Table 3 [24,26,42-50]. 
Table 2. Emerging evidence of coffee or caffeine treatment on various liver diseases.

\begin{tabular}{|c|c|c|}
\hline References & $\begin{array}{l}\text { Experimental } \\
\text { Model }\end{array}$ & Major Findings \\
\hline Wiltberger et al. [28] & Human & $\begin{array}{l}\text { Coffee consumption was associated with a decreased risk of } \\
\text { hepatocellular carcinoma recurrence and increased survival } \\
\text { following orthotopic liver transplantation. }\end{array}$ \\
\hline Nishitsuji et al. [29] & Mice & $\begin{array}{c}\text { Caffeine would affect the gut dysbiosis and the disrupted plasma } \\
\text { short-chain fatty acid profile, then subsequently prevented } \\
\text { nonalcoholic steatohepatitis. }\end{array}$ \\
\hline Veronese et al. [30] & Human & $\begin{array}{l}\text { The consumption of coffee was not associated with liver steatosis } \\
\text { either nonalcoholic fatty liver disease or alcoholic fatty liver disease. }\end{array}$ \\
\hline Kennedy et al. [31] & Human & $\begin{array}{l}\text { Increased consumption of caffeinated and decaffeinated coffee is } \\
\text { associated with reduced risk of hepatocellular carcinoma, including } \\
\text { in pre-existing liver disease. }\end{array}$ \\
\hline Arauz et al. [31] & Rats & $\begin{array}{l}\text { Coffee prevented liver cirrhosis by attenuating the oxidant process, } \\
\text { blocking hepatic stellate cell activation, and down-regulated the } \\
\text { profibrotic molecules. }\end{array}$ \\
\hline $\begin{array}{l}\text { Wijarnpreecha et al. } \\
\text { [33] }\end{array}$ & Human & $\begin{array}{l}\text { Coffee consumption showed a decreased risk of advanced liver } \\
\text { fibrosis and inflammation among hepatitis C-infected patients. }\end{array}$ \\
\hline Hsu et al. [6] & Rats & $\begin{array}{l}\text { Caffeine decreased portal pressures, ameliorated hyperdynamic } \\
\text { circulation, protosystemic collateral shunting, mesenteric } \\
\text { angiogenesis and liver fibrosis in cirrhotic rats. }\end{array}$ \\
\hline Lammert et al. [34] & Human & $\begin{array}{l}\text { Coffee consumption was lower among patients with primary } \\
\text { sclerosing cholangitis, but no primary biliary cholangitis, compared } \\
\text { with controls. }\end{array}$ \\
\hline Barcelos et al. [35] & Rats & $\begin{array}{l}\text { Caffeine modified the hepatic responses associated to } \\
\text { exercise-induced oxidative stress of trained rats. }\end{array}$ \\
\hline Sinha et al. [36] & Mice & $\begin{array}{c}\text { The caffeine's lipolytic action was through autophage in } \\
\text { mammalian liver and it was a potent stimulator of hepatic } \\
\text { autophagic flux. }\end{array}$ \\
\hline Li et al. [37] & Cells & $\begin{array}{c}\text { The caffeine-enhanced autophagic flux in hepatic stellate cell (HSC) } \\
\text { was stimulated by endoplasmic reticulum stress, which further } \\
\text { weakened HSC viability via the induction of apoptosis. }\end{array}$ \\
\hline Ikeda et al. [38] & Human & $\begin{array}{c}\text { There was an inverse association between coffee consumption and } \\
\text { elevated aminotransferase in men, and it was more evident in those } \\
\text { with high alcohol consumption and in those with low body mass } \\
\text { index. }\end{array}$ \\
\hline Ong et al. [39] & Human & $\begin{array}{l}\text { Caffeine intake does not affect liver stiffness in chronic hepatitis } \\
\text { B-infected patients. }\end{array}$ \\
\hline Kurozawa et al. [40] & Human & $\begin{array}{c}\text { An inverse association between coffee consumption and HCC } \\
\text { mortality was found in a large cohort study in Japan. }\end{array}$ \\
\hline Ohta et al. [41] & Rats & $\begin{array}{l}\text { A high dose of caffeine }(100 \mathrm{mg} / \mathrm{kg}) \text { completely blocked both liver } \\
\text { damage and proinflammatory cytokine responses through an } \\
\text { A2AR-independent mechanism. }\end{array}$ \\
\hline
\end{tabular}

In conclusion, caffeine ameliorated liver fibrosis and reduced portal pressure without adversely affecting systemic hemodynamics in cirrhotic rats. However, caffeine did not ameliorate HPS. Further study of longer treatment durations, prophylactic caffeine treatment applied at the beginning of liver injury or co-treatment with other anti-inflammatory drugs, such as rosuvastatin or TNF- $\alpha$ blockade agents, might be useful to address this issue. 


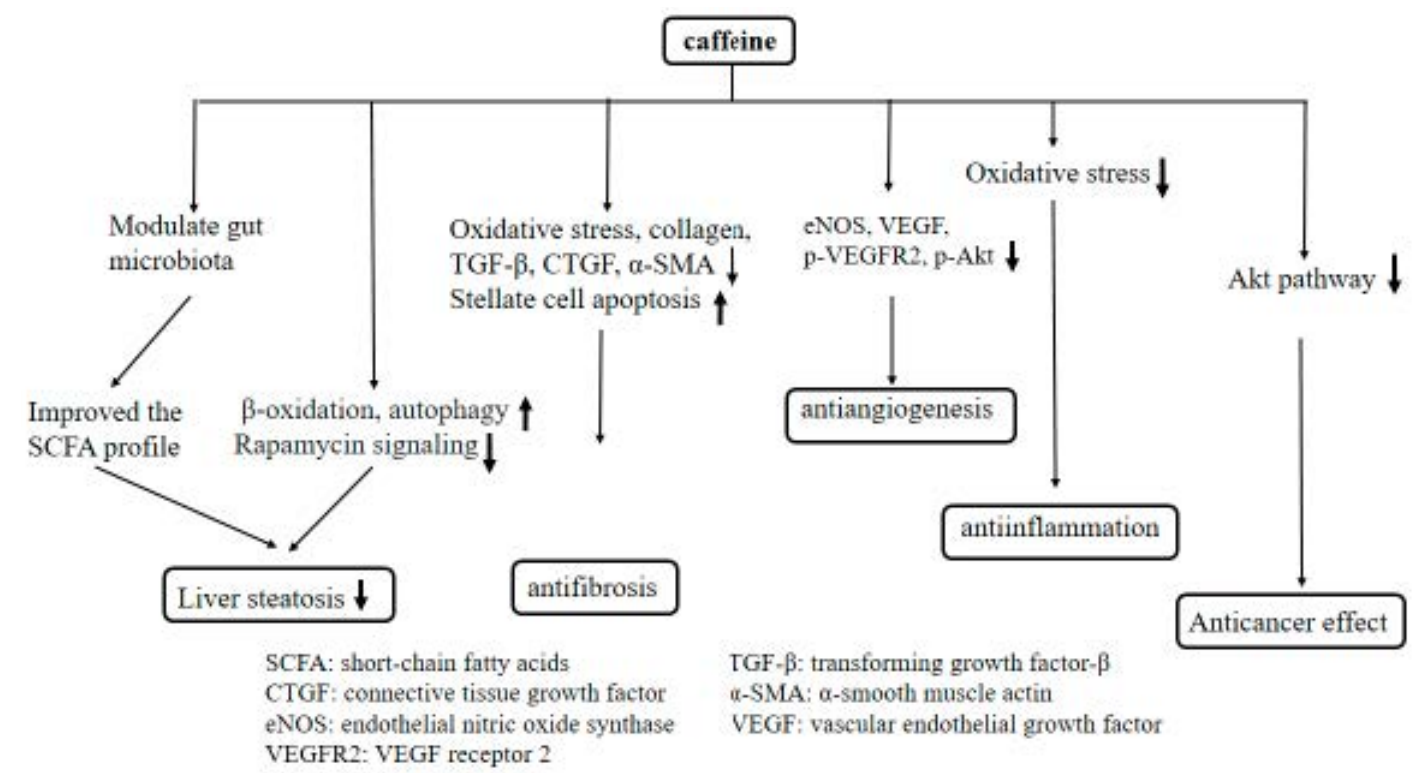

Figure 3. The postulated mechanisms regarding the effect of caffeine on the liver.

Table 3. Emerging evidence of coffee or caffeine treatment on various lung diseases.

\begin{tabular}{|c|c|c|}
\hline References & $\begin{array}{l}\text { Experimental } \\
\text { Model }\end{array}$ & Major Findings \\
\hline Amaral et al. [42] & Mice & $\begin{array}{l}\text { Caffeine enhanced the frequency and number of parenchymal CD4+ } \\
\text { T-cell and stimulated immune function in severe tuberculosis. }\end{array}$ \\
\hline Doyle et al. [43] & Human & $\begin{array}{l}\text { Caffeine reduced the incidence of brochopulmonary dysplasia in the } \\
\text { new-born period and improved pulmonary function at follow-up. }\end{array}$ \\
\hline Jing et al. [44] & Rats & $\begin{array}{l}\text { Early caffeine treatment could protect immature lungs from } \\
\text { hyperoxia-induced lung injury. }\end{array}$ \\
\hline Fehrholz et al. [24] & Cells & $\begin{array}{l}\text { Glucocorticoid had adverse effects on long-term remodeling by } \\
\text { induction of connective tissue growth factor in lung cells, however, } \\
\text { co-treatment with caffeine attenuated connective tissue growth factor } \\
\text { expression and promoting restoration of lung homeostatsis. }\end{array}$ \\
\hline Tatler et al. [45] & Cells & $\begin{array}{l}\text { Caffeine owned anti-fibrotic capacities for the epithelial cells and } \\
\text { fibroblasts in the lung. }\end{array}$ \\
\hline Chou et al. [46] & Rats & $\begin{array}{l}\text { Caffeine could mitigate lung inflammation induced by } \\
\text { ischemia-reperfusion of the lower limbs. }\end{array}$ \\
\hline Guertin et al. [47] & Human & Coffee drinking was positively associated with lung cancer. \\
\hline Wang et al. [48] & Cells & $\begin{array}{l}\text { Caffeine administration increased the cisplatin-induced lung cancer } \\
\text { killings and cellular apoptosis. }\end{array}$ \\
\hline Li et al. [26] & Mice & $\begin{array}{c}\text { Caffeine either enhanced lung damage by antagonizing A2A receptor } \\
\text { or exerted protection against lung damage via A2A } \\
\text { receptor-independent mechanisms, depending on the timing of } \\
\text { exposure and dose of administration. }\end{array}$ \\
\hline Lu et al. [49] & Cells & $\begin{array}{l}\text { Caffeine and tea polyphenos inhibited the progression of lung } \\
\text { adenoma to adenocarcinoma. }\end{array}$ \\
\hline Yoder et al. [50] & Baboons & $\begin{array}{l}\text { Early caffeine treatments were associated with better lung function in } \\
\text { immature baboons. }\end{array}$ \\
\hline
\end{tabular}

On the other hand, we drew the postulated mechanisms regarding the effect of caffeine on the liver (Figure 3) and lung (Figure 4). 


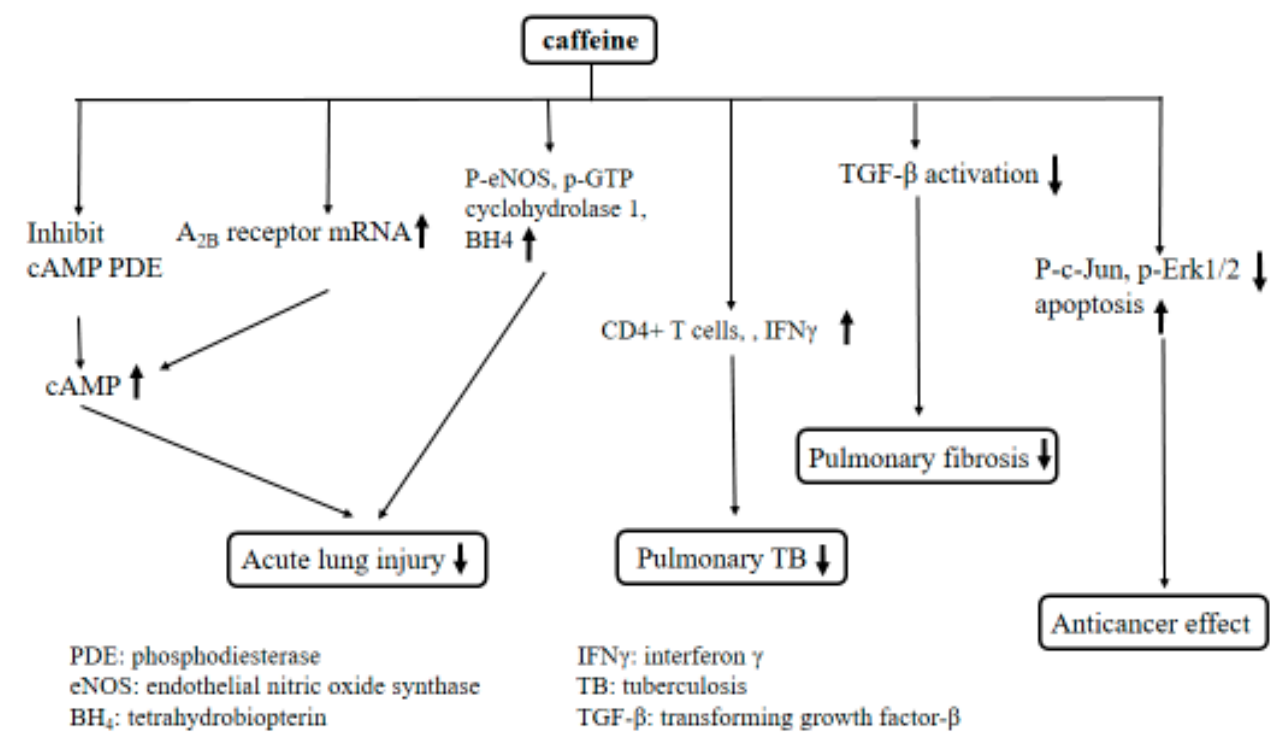

Figure 4. The postulated mechanisms regarding the effect of caffeine on the lung.

\section{Materials and Methods}

\subsection{Animal Model}

Male Sprague-Dawley rats weighing 240-270 $\mathrm{g}$ at the time of surgery were used. Rats were housed in plastic cages and allowed free access to food and water. Common bile duct ligation (CBDL) was applied as an animal model of liver cirrhosis with HPS according to previous reports $[10,11,14]$. The rats were fasted for $12 \mathrm{~h}$ before the operation. Under Zoletil 50 (Tiletamine + Zolezepam) anesthesia (0.8 mg $/ \mathrm{kg}$, intramuscularly), CBDL was performed. A high yield of secondary biliary cirrhosis was noted four weeks after the ligation [51]. To avoid coagulation defects, CBDL rats received weekly vitamin $\mathrm{K}$ injections (50 $\mathrm{gg} / \mathrm{kg}$ intramuscularly). In all experiments, the principles of laboratory animal care (NIH publication no. 86-23, revised 1985) were followed. This study was approved by the Taipei Veterans General Hospital Animal Committee (IACUC 2017-060) (21/6/2017).

\subsection{Experimental Design}

In humans with moderate to high caffeine intake, doses approximate 10-20 mg/ $\mathrm{kg} / \mathrm{day}$ [52]. Based on a report from Ohta et al. that the amount of caffeine in a single cup of coffee (100 mg) is estimated to be equivalent to a $5 \mathrm{mg} / \mathrm{kg}$ dose in rodents, 5 and $15 \mathrm{mg} / \mathrm{kg}$ can be considered low-dose caffeine treatment, while $50 \mathrm{mg} / \mathrm{kg}$ caffeine administration is a high-dose caffeine treatment in mouse model [41]. In the present study, we used caffeine $50 \mathrm{mg} / \mathrm{kg} /$ day as a high-dose caffeine treatment to investigate the beneficial effect of cirrhotic rats. CBDL rats were fed via oral gavage with $50 \mathrm{mg} / \mathrm{kg} / \mathrm{day}$ caffeine or vehicle (distilled water $5 \mathrm{~mL} /$ day, control group) from the 15th to 28th day after CBDL. On the 28th day after CBDL, the body weight, mortality rate, and hemodynamic data were measured. Arterial blood was collected for gas analysis. Venous blood was collected for determination of TB, AST, ALT, and creatinine. Furthermore, lung and liver were dissected for histological examination and immunohistochemical staining to evaluate liver fibrosis, intrahepatic and intrapulmonary angiogenesis and inflammation. Protein expressions were analyzed with Western blotting. In another series with parallel groups, the intrapulmonary shunting was determined with the color microsphere method.

\subsection{Systemic and Portal Hemodynamic Measurements}

The right internal carotid artery was cannulated with a PE-50 catheter that was connected to a Spectramed DTX transducer (Spectramed Inc., Oxnard, CA, USA). Continuous recordings of mean arterial pressure were performed on a multi-channel recorder (model RS 3400, Gould Inc., 
Cupertino, CA, USA). The external zero reference was placed at the level of the mid-portion of the rat. The abdomen was then opened with a midline incision, and the superior mesenteric vein was cannulated with a PE-50 catheter connected to a Spectramed DTX transducer. The abdominal cavity was closed, and the PP was recorded on a Gould model RS 3400 recorder.

\subsection{Biochemistry and Blood Gas Analysis}

The femoral artery and vein were cannulated with PE-50 catheters, one day before the experiments. Both catheters were fixed over the back and flushed with a heparin-contained solution. Blood was withdrawn from the femoral vein to determine plasma concentrations of ALT, AST, TB, and creatinine. Arterial blood was withdrawn from the femoral artery for blood gas analysis. Arterial gas exchange was evaluated by the alveolar-arterial oxygen gradient, which was calculated as $150-\left(\mathrm{PaCO}_{2} / 0.8\right)-\mathrm{PaO}_{2}$.

\subsection{Histopathological and Immunochemical Staining}

Liver and lung were dissected free and fixed in 10\% neutral buffered formalin. The sections were stained with H\&E and examined by light microscopy. The liver sections were stained with Sirius red for 8 min according to the manufacturer's instructions (Polysciences Inc., Warrington, PA, USA) to determine the extent of collagen deposition [53]. The immunochemical staining was performed with anti-CD68 antibody (diluted 1:200, ab31630, Abcam Cambridge, UK) to detect pulmonary CD68-positive macrophages, indicating the severity of intrapulmonary inflammation. To determine the intrahepatic angiogenesis, immunochemical staining with anti-CD31 antibody (1:200, Serotec and Pharmingen, San Diego, CA, USA) was performed [6]. Anti-vWF antibody (1:100, MCA127T, AbD Serotec, UK) was applied to survey the intrapulmonary angiogenesis [54]. The immunochemical staining was followed by the biotinylated anti-mouse $\operatorname{IgG}(\mathrm{H}+\mathrm{L})$ (Vector Laboratories, Burlingame, CA, USA) as the second antibody. Detection of biotinylated antibody was performed using the VECTASTAIN $^{\circledR}$-Elite ABC kit from Vector Laboratories. For the chromogen, DAB ( $3^{\prime}$-diaminobenzidine tetrahydrochloride) was used, which resulted in a brown color at the antigen site.

\subsection{Western Blot Analysis for Protein Expressions}

Lung and liver were immediately frozen in liquid nitrogen and stored at $-80^{\circ} \mathrm{C}$ until required. Protein was extracted by pulverization in grinder with liquid nitrogen, followed by $1 \mathrm{~mL}$ of lysis buffer (phosphate-buffered solution containing $1 \%$ Nonidet P- $40,0.5 \%$ sodium deoxycholate, $0.1 \%$ sodium dodecyl sulfate (SDS)) and $0.05 \%$ protease inhibitor cocktail solution (Roche Diagnostics GmbH, Penzberg, Germany) for each $100 \mathrm{mg}$ powdered sample. Protein concentration was determined for each sample by the Bradford method [55]. An aliquot of 20-40 $\mu \mathrm{g}$ protein from each sample that dissolved in sample buffer (63 mmol/1 of Tris-HCL, $\mathrm{pH} 6.8$, containing $2 \%$ SDS, $10 \%$ glycerol, $5 \%$ 2-mercaptoethanol, and $0.005 \%$ bomphenol blue) and $10 \mu \mathrm{g}$ positive control were separated on denaturing SDS- $10 \%$ polyacrylamide gels by electrophoresis (Mini-PROTEAN ${ }^{\circledR} 3$ Cell, Bio-Rad Laboratories, Hercules, CA, USA). Pre-stained proteins markers (SDS-PAGE Standards, Bio-Rad) were used for molecular weight determination. Proteins were then transferred to a polyvinylidene difluoride membrane (Immum-Blot ${ }^{\mathrm{TM}}$ PVDF Membrane, Bio-Rad) by a semi-dry electroblotting system (Trans-Blot ${ }^{\circledR}$ SD Semi-dry Electrophoretic Transfer Cell, Bio-Rad) for $1.5 \mathrm{~h}$ at $4{ }^{\circ} \mathrm{C}$. To block non-specific binding, membranes were blocked for $30 \mathrm{~min}$ with $3 \%$ non-fat dry milk in TBS-T, pH 7.4 ( 25 mmol/1 Tris base- $137 \mathrm{mmol} / 1 \mathrm{NaCl}-2.7 \mathrm{mmol} / 1 \mathrm{KCL}-1 \%$ Tween 20$)$. Blots were incubated with the primary antibody [anti-PI ${ }_{3}$ K (1:1000; Cell Signaling Technology), anti-NF-кB p65 (1:200; Santa Cruz Biotechnology, Santa Cruz, CA, USA), anti-phosphorylated-NF-kB p65 (1:1000; Abcam plc, Cambridge, UK), anti-VEGF (1:1000; Santa Cruz Biotechnology), anti-RhoA (1:1000; Cell Signaling Technology), anti-Akt (1:500, Cell Signaling Technology), anti-phosphorylated Akt (1:2000, Cell Signaling Technology), anti-ERK, -phosphorylated ERK (1:3000, Millipore Corporation), diluted with 3\% non-fat dry milk in TBS-T] for $90 \mathrm{~min}$ at room temperature and washed. Then the blots were incubated for $90 \mathrm{~min}$ with the secondary antibody (horseradish peroxidase-conjugated goat anti-mouse IgG antibody, diluted with 
$3 \%$ non-fat dry milk in TBS-T, Sigma Chemical Co., St. Louis, MO, USA) and washed. The specific proteins were detected by enhanced chemiluminescence (Immobilon Western Chemiluminescent HRP Substrate, Merk Millipore Co., Billerica, MA, USA). With a computer-assisted video densitometer and digitalized system (BioSpectrum ${ }^{\circledR} 600$ Imaging System, Ultra-Violet Products Ltd., Upland, CA, USA), the blots were scanned and photographed, after which the signal intensity (integral volume) of the appropriate band was analyzed.

\subsection{Intrapulmonary Shunting Analysis}

The degree of intrapulmonary shunting was determined using the color microsphere method [14]. Before microsphere injection, indwelling PE-50 femoral arterial and venous catheters were placed. On the day of measurement, $2.5 \times 10^{6}$ custom mixed and counted cross-linked polystyrene-divinylbenzene microspheres labeled red (size range 6.5-10 $\mu \mathrm{m}$; Interactive Medical Technologies, Los Angeles, CA) in $0.20 \mathrm{~mL}$ of sterile PBS were injected over 2-4 s through the femoral vein catheter, which was immediately flushed with $0.2 \mathrm{~mL}$ of sterile PBS over $2-4 \mathrm{~s}$. A reference blood sample was withdrawn from the femoral arterial catheter started at the time of femoral vein injection for a total of $90 \mathrm{~s}$ at a constant rate of $1.0 \mathrm{~mL} / \mathrm{min}$. The volume removed was replaced with an equal volume of sterile PBS. Samples of beads before venous injection and reference blood samples were coded. The numbers of colored microspheres in the blood preparations were determined using a hemacytometer counting slide having a known volume. Because the diameter of normal pulmonary microvasculature was less than $5 \mu \mathrm{m}$, most part of microsphere beads injected from femoral vein would be trapped in the lung. However, microspheres would pass through the intrapulmonary shunting vessels in the HPS animal and were collected in the reference blood from the femoral artery. Total numbers of microspheres passing through the pulmonary microcirculation were calculated as reference blood sample microspheres per $\mathrm{mL}$ times estimated blood volume. Estimated blood volume $(\mathrm{mL})$ was calculated as: $0.06 \mathrm{x}$ body wt $(\mathrm{g})+0.77$ [56]. Intrapulmonary shunting (\%) was calculated as: (total number of microspheres passing through the pulmonary microcirculation/total beads injected into the venous circulation) $\times 100$.

\subsection{Drugs}

Caffeine was purchased from Sigma Chemical Co. (St. Louis, MO, USA).

\subsection{Data Analysis}

The results are expressed as mean \pm standard deviation. Statistical analyses were performed with Student's t test. The survival rate was analyzed with log-rank test. Results were considered statistically significant at a $p$-value less than 0.05 .

Supplementary Materials: Supplementary can be found at http://www.mdpi.com/1422-0067/20/7/1566/s1.

Author Contributions: Conceptualization, C.-C.C.; Data curation, C.-L.C.; Formal analysis, C.-L.C. and I.-F.H.; Funding acquisition, C.-C.C.; Methodology, M.-H.T. and S.-J.H.; Project administration, H.-C.H. and F.-Y.L.; Software, S.-J.H.; Supervision, H.-C.H., F.-Y.L. and S.-D.L.; Visualization, M.-H.T. and I.-F.H.; Writing-original draft, C.-C.C.; Writing-review \& editing, H.-C.H.

Funding: This work was supported by a grant from the Taipei Veterans General Hospital (V107C-026), and the Szu-Zuan Research Foundation of Internal Medicine (No. 108009), Taipei, Taiwan.

Acknowledgments: We gratefully acknowledge for the Clinical Research Core Laboratory of Taipei Veterans General Hospital for providing experimental space and facilities.

Conflicts of Interest: The authors declare no conflict of interest 


\section{References}

1. Ruhl, C.E.; Everhart, J.E. Coffee and tea consumption are associated with a lower incidence of chronic liver disease in the United States. Gastroenterology 2005, 129, 1928-1936. [CrossRef] [PubMed]

2. Modi, A.A.; Feld, J.J.; Park, Y.; Kleiner, D.E.; Everhart, J.E.; Liang, T.J.; Hoofnagle, J.H. Increased caffeine consumption is associated with reduced hepatic fibrosis. Hepatology 2010, 51, 201-209. [CrossRef] [PubMed]

3. Larsson, S.C.; Wolk, A. Coffee consumption and risk of liver cancer: A meta-analysis. Gastroenterology 2007, 132, 1740-1745. [CrossRef] [PubMed]

4. Li, H.; Jin, S.Y.; Son, H.J.; Seo, J.H.; Jeong, G.B. Caffeine-induced endothelial cell death and the inhibition of angiogenesis. Anat. Cell Biol. 2013, 46, 57-67. [CrossRef] [PubMed]

5. Köroğlu, O.A.; MacFarlane, P.M.; Balan, K.V.; Zenebe, W.J.; Jafri, A.; Martin, R.J.; Kc, P. Anti-inflammatory effect of caffeine is associated with improved lung function after lipopolysaccharide-induced amnionitis. Neonatology 2014, 106, 235-240. [CrossRef] [PubMed]

6. Hsu, S.J.; Lee, F.Y.; Wang, S.S.; Hsin, I.F.; Lin, T.Y.; Huang, H.C.; Chang, C.C.; Chuang, C.L.; Ho, H.L.; Lin, H.C.; Lee, S.D. Caffeine ameliorates hemodynamic derangements and portosystemic collaterals in cirrhotic rats. Hepatology 2015, 61, 1672-1684.

7. Koch, D.G.; Fallon, M.B. Hepatopulmonary syndrome. Curr. Opin. Gastroenterol. 2014, 30, $260-264$. [CrossRef]

8. Schenk, P.; Fuhrmann, V.; Madl, C.; Funk, G.; Lehr, S.; Kandel, O.; Müller, C. Hepatopulmonary syndrome: Prevalence and predictive value of various cut offs for arterial oxygenation and their clinical consequences. Gut 2002, 51, 853-859. [CrossRef]

9. Swanson, K.L.; Wiesner, R.H.; Krowka, M.J. Natural history of hepatopulmonary syndrome: Impact of liver transplantation. Hepatology 2005, 41, 1122-1129. [CrossRef]

10. Zhang, J.; Luo, B.; Tang, L.; Wang, Y.; Stockard, C.R.; Kadish, I.; Van Groen, T.; Grizzle, W.E.; Ponnazhagan, S.; Fallon, M.B. Pulmonary angiogenesis in a rat model of hepatopulmonary syndrome. Gastroenterology 2009, 136, 1070-1080. [CrossRef]

11. Zhang, J.; Fallon, M.B. Hepatopulmonary syndrome: Update on pathogenesis and clinical features. Nat. Rev. Gastroenterol. Hepatol. 2012, 9, 539-549. [CrossRef] [PubMed]

12. Berthelot, P.; Walker, J.G.; Sherlock, S.; Reid, L. Arterial changes in the lungs in cirrhosis of the liver-lung spider nevi. N. Engl. J. Med. 1966, 274, 291-298. [CrossRef] [PubMed]

13. Edell, E.S.; Cortese, D.A.; Krowka, M.J.; Rehder, K. Severe hypoxemia and liver disease. Am. Rev. Respir. Dis. 1989, 140, 1631-1635. [CrossRef] [PubMed]

14. Chang, C.C.; Chuang, C.L.; Lee, F.Y.; Wang, S.S.; Lin, H.C.; Huang, H.C.; Teng, T.H.; Hsu, S.J.; Hsieh, H.G.; Lee, S.D. Sorafenib treatment improves hepatopulmonary syndrome in rats with biliary cirrhosis. Clin. Sci. 2013, 124, 457-466. [CrossRef] [PubMed]

15. Zhang, J.; Yang, W.; Luo, B.; Hu, B.; Maheshwari, A.; Fallon, M.B. The role of $\mathrm{CX}_{3} \mathrm{CL1}$ /CX ${ }_{3} \mathrm{CR} 1$ in pulmonary angiogenesis and intravascular monocyte accumulation in rat experimental hepatopulmonary syndrome. J. Hepatol. 2012, 57, 752-758. [CrossRef] [PubMed]

16. Thenappan, T.; Goel, A.; Marsboom, G.; Fang, Y.H.; Toth, P.T.; Zhang, H.J.; Kajimoto, H.; Hong, Z.; Paul, J.; Wietholt, C.; et al. A central role for CD68 (+) macrophages in hepatopulmonary syndrome. Reversal by macrophage depletion. Am. J. Respir. Crit. Care Med. 2011, 183, 1080-1091. [CrossRef]

17. Chang, C.C.; Wang, S.S.; Hsieh, H.G.; Lee, W.S.; Chuang, C.L.; Lin, H.C.; Lee, F.Y.; Lee, S.D.; Huang, H.C. Rosuvastatin improves hepatopulmonary syndrome through inhibition of inflammatory angiogenesis of lung. Clin. Sci. 2015, 129, 449-460. [CrossRef]

18. Cachón, A.U.; Quintal-Novelo, C.; Medina-Escobedo, G.; Castro-Aguilar, G.; Moo-Puc, R.E. Hepatoprotective effect of low doses of caffeine on CCl4-Induced liver damage in rats. J. Diet Suppl. 2017, 14, $158-172$. [CrossRef]

19. Furtado, K.S.; Prado, M.G.; Aguiar, E.; Silva, M.A.; Dias, M.C.; Rivelli, D.P.; Rodrigues, M.A.; Barbisan, L.F. Coffee and caffeine protect against liver injury induced by thioacetamide in male Wistar rats. Basic Clin. Pharmacol. Toxicol. 2012, 111, 339-347. [CrossRef]

20. Costenla, A.R.; Cunha, R.A.; de Mendonça, A. Caffeine, adenosine receptors, and synaptic plasticity. J. Alzheimers. Dis. 2010, 20, S25-S34. [CrossRef] 
21. Chan, E.S.; Montesinos, M.C.; Fernandez, P.; Desai, A.; Delano, D.L.; Yee, H.; Reiss, A.B.; Pillinger, M.H.; Chen, J.F.; Schwarzschild, M.A.; et al. Adenosine A (2A) receptors play a role in the pathogenesis of hepatic cirrhosis. Br. J. Pharmacol. 2006, 148, 1144-1155. [CrossRef] [PubMed]

22. Hagberg, H.; Andersson, P.; Lacarewicz, J.; Jacobson, I.; Butcher, S.; Sandberg, M. Extracellular adenosine, inosine, hypoxanthine, and xanthine in relation to tissue nucleotides and purines in rat striatum during transient ischemia. J. Neurochem. 1987, 49, 227-231. [CrossRef] [PubMed]

23. Adair, T.H. Growth regulation of the vascular system: An emerging role for adenosine. Am. J. Physiol. Regul. Integr. Comp. Physiol. 2005, 289, R283-R296. [CrossRef] [PubMed]

24. Fehrholz, M.; Glaser, K.; Speer, C.P.; Seidenspinner, S.; Ottensmeier, B.; Kunzmann, S. Caffeine modulates glucocorticoid-induced expression of CTGF in lung epithelial cells and fibroblasts. Respir. Res. 2017, 18, 51. [CrossRef] [PubMed]

25. Loftfield, E.; Freedman, N.D.; Graubard, B.I.; Guertin, K.A.; Black, A.; Huang, W.Y.; Shebl, F.M.; Mayne, S.T.; Sinha, R. Association of coffee consumption with overall and cause-specific mortality in a large US prospective cohort study. Am. J. Epidemiol. 2015, 182, 1010-1022. [CrossRef] [PubMed]

26. Li, J.; Li, G.; Hu, J.L.; Fu, X.H.; Zeng, Y.J.; Zhou, Y.G.; Xiong, G.; Yang, N.; Dai, S.S.; He, F.T. Chronic or high dose acute caffeine treatment protects mice against oleic acid-induced acute lung injury via an adenosine A2A receptor-independent mechanism. Eur. J. Pharmacol. 2011, 654, 295-303. [CrossRef] [PubMed]

27. Sztrymf, B.; Rabiller, A.; Nunes, H.; Savale, L.; Lebrec, D.; Le Pape, A.; de Montpreville, V.; Mazmanian, M.; Humbert, M.; Hervé, P. Prevention of hepatopulmonary syndrome by pentoxifylline in cirrhotic rats. Eur. Respir. J. 2004, 23, 752-758. [CrossRef] [PubMed]

28. Wiltberger, G.; Wu, Y.; Lange, U.; Hau, H.M.; Tapper, E.; Krenzien, F.; Atanasov, G.; Benzing, C.; Feldbrügge, L.; Csizmadia, E.; et al. Protective effects of coffee consumption following liver transplantation for hepatocellular carcinoma in cirrhosis. Aliment. Pharmacol. Ther. 2019, 49, 779-788. [CrossRef] [PubMed]

29. Nishitsuji, K.; Watanabe, S.; Xiao, J.; Nagatomo, R.; Ogawa, H.; Tsunematsu, T.; Umemoto, H.; Morimoto, Y.; Akatsu, H.; Inoue, K.; et al. Effect of coffee or coffee components on gut microbiome and short-chain fatty acids in a mouse model of metabolic syndrome. Sci. Rep. 2018, 8, 16173. [CrossRef]

30. Veronese, N.; Notarnicola, M.; Cisternino, A.M.; Reddavide, R.; Inguaggiato, R.; Guerra, V.; Rotolo, O.; Zinzi, I.; Leandro, G.; Correale, M.; et al. Coffee intake and liver steatosis: A population study in a Mediterranean area. Nutrients 2018, 10, 89. [CrossRef] [PubMed]

31. Kennedy, O.J.; Roderick, P.; Buchanan, R.; Fallowfield, J.A.; Hayes, P.C.; Parkes, J. Coffee, including caffeinated and decaffeinated coffee, and the risk of hepatocellular carcinoma: A systematic review and dose-response meta-analysis. BMJ Open 2017, 7, e013739. [CrossRef]

32. Arauz, J.; Zarco, N.; Hernández-Aquino, E.; Galicia-Moreno, M.; Favari, L.; Segovia, J.; Muriel, P. Coffee consumption prevents fibrosis in a rat model that mimics secondary biliary cirrhosis in humans. Nutr. Res. 2017, 40, 65-74. [CrossRef] [PubMed]

33. Wijarnpreecha, K.; Thongprayoon, C.; Ungprasert, P. Impact of caffeine in hepatitis C virus infection: A systematic review and meta-analysis. Eur. J. Gastroenterol. Hepatol. 2017, 29, 17-22. [CrossRef]

34. Lammert, C.; Juran, B.D.; Schlicht, E.; Xie, X.; Atkinson, E.J.; de Andrade, M.; Lazaridis, K.N. Reduced coffee consumption among individuals with primary sclerosing cholangitis but not primary biliary cirrhosis. Clin. Gastroenterol. Hepatol. 2014, 12, 1562-1568. [CrossRef]

35. Barcelos, R.P.; Souza, M.A.; Amaral, G.P.; Stefanello, S.T.; Bresciani, G.; Fighera, M.R.; Soares, F.A.; Barbosa, N.V. Caffeine supplementation modulates oxidative stress markers in the liver of trained rats. Life Sci. 2014, 96, 40-45. [CrossRef] [PubMed]

36. Sinha, R.A.; Farah, B.L.; Singh, B.K.; Siddique, M.M.; Li, Y.; Wu, Y.; Ilkayeva, O.R.; Gooding, J.; Ching, J.; Zhou, J.; et al. Caffeine stimulates hepatic lipid metabolism by the autophagy-lysosomal pathway in mice. Hepatology 2014, 59, 1366-1380. [CrossRef] [PubMed]

37. Li, Y.; Chen, Y.; Huang, H.; Shi, M.; Yang, W.; Kuang, J.; Yan, J. Autophagy mediated by endoplasmic reticulum stress enhances the caffeine-induced apoptosis of hepatic stellate cells. Int. J. Mol. Med. 2017, 40, 1405-1414. [CrossRef] [PubMed]

38. Ikeda, M.; Maki, T.; Yin, G.; Kawate, H.; Adachi, M.; Ohnaka, K.; Takayanagi, R.; Kono, S. Relation of coffee consumption and serum liver enzymes in Japanese men and women with reference to effect modification of alcohol use and body mass index. Scand. J. Clin. Lab. Investig. 2010, 70, 171-179. [CrossRef] [PubMed] 
39. Ong, A.; Wong, V.W.; Wong, G.L.; Chan, H.L. The effect of caffeine and alcohol consumption on liver fibrosis-A study of 1045 Asian hepatitis B patients using transient elastography. Liver Int. 2011, 31, 1047-1053. [CrossRef] [PubMed]

40. Kurozawa, Y.; Ogimoto, I.; Shibata, A.; Nose, T.; Yoshimura, T.; Suzuki, H.; Sakata, R.; Fujita, Y.; Ichikawa, S.; Iwai, N.; et al. Coffee and risk of death from hepatocellular carcinoma in a large cohort study in Japan. Br. J. Cancer 2005, 93, 607-610. [CrossRef]

41. Ohta, A.; Lukashev, D.; Jackson, E.K.; Fredholm, B.B.; Sitkovsky, M. 1,3,7-trimethylxanthine (caffeine) may exacerbate acute inflammatory liver injury by weakening the physiological immunosuppressive mechanism. J. Immunol. 2007, 179, 7431-7438. [CrossRef]

42. Amaral, E.P.; Machado de Salles, É.; Barbosa Bomfim, C.C.; Salgado, R.M.; Almeida, F.M.; de Souza, P.C.; Alvarez, J.M.; Hirata, M.H.; Lasunskaia, E.B.; D’Império-Lima, M.R. Inhibiting Adenosine Receptor Signaling Promotes Accumulation of Effector CD4+ T Cells in the Lung Parenchyma During Severe Tuberculosis. J. Infect. Dis. 2019, 219, 964-974. [CrossRef] [PubMed]

43. Doyle, L.W.; Ranganathan, S.; Cheong, J.L.Y. Neonatal caffeine treatment and respiratory function at 11 years in children under $1.251 \mathrm{~g}$ at birth. Am. J. Respir. Crit. Care Med. 2017, 196, 1318-1324. [CrossRef] [PubMed]

44. Jing, X.; Huang, Y.W.; Jarzembowski, J.; Shi, Y.; Konduri, G.G.; Teng, R.J. Caffeine ameliorates hyperoxia-induced lung injury by protecting GCH1 function in neonatal rat pups. Pediatr. Res. 2017, 82, 483-489. [CrossRef] [PubMed]

45. Tatler, A.L.; Barnes, J.; Habgood, A.; Goodwin, A.; McAnulty, R.J.; Jenkins, G. Caffeine inhibits TGF $\beta$ activation in epithelial cells, interrupts fibroblast responses to TGF $\beta$, and reduces established fibrosis in ex vivo precision-cut lung slices. Thorax 2016, 71, 565-567. [CrossRef] [PubMed]

46. Chou, W.C.; Kao, M.C.; Yue, C.T.; Tsai, P.S.; Huang, C.J. Caffeine mitigates lung inflammation induced by ischemia-reperfusion of lower limbs in rats. Mediators Inflamm. 2015, 2015, 361638. [CrossRef]

47. Guertin, K.A.; Freedman, N.D.; Loftfield, E.; Graubard, B.I.; Caporaso, N.E.; Sinha, R. Coffee consumption and incidence of lung cancer in the NIH-AARP Diet and Health Study. Int. J. Epidemiol. 2016, 45, 929-939. [CrossRef] [PubMed]

48. Wang, G.; Bhoopalan, V.; Wang, D.; Wang, L.; Xu, X. The effect of caffeine on cisplatin-induced apoptosis of lung cancer cells. Exp. Hematol. Oncol. 2015, 4, 5. [CrossRef]

49. Lu, G.; Liao, J.; Yang, G.; Reuhl, K.R.; Hao, X.; Yang, C.S. Inhibition of adenoma progression to adenocarcinoma in a 4-(methylnitrosamino)-1-(3-pyridyl)-1-butanone-induced lung tumorigenesis model in A/J mice by tea polyphenols and caffeine. Cancer Res. 2006, 66, 11494-11501. [CrossRef]

50. Yoder, B.; Thomson, M.; Coalson, J. Lung function in immature baboons with respiratory distress syndrome receiving early caffeine therapy: A pilot study. Acta. Paediatr. 2005, 94, 92-98. [CrossRef]

51. Franco, F.; Gigou, M.; Szekely, A.M.; Bismuth, H. Portal hypertension after bile duct obstruction: Effect of bile diversion on portal pressure in the rat. Arch. Surg. 1979, 114, 1064-1067. [CrossRef] [PubMed]

52. Stavric, B.; Klassen, R.; Watkinson, B.; Karpinski, K.; Stapley, R.; Fried, P. Variability in caffeine consumption from coffee and tea: Possible significance for epidemiological studies. Food Chem. Toxicol. 1988, 26, 111118. [CrossRef]

53. Whittaker, P.; Kloner, R.A.; Boughner, D.R.; Pickering, J.G. Quantitative assessment of myocardial collagen with picrosirius red staining and circularly polarized light. Basic Res. Cardiol. 1994, 89, 397-410. [CrossRef] [PubMed]

54. Zanetta, L.; Marcus, S.G.; Vasile, J.; Dobryansky, M.; Cohen, H.; Eng, K.; Shamamian, P.; Mignatti, P. Expression of von Willebrand factor, an endothelial cell marker, is up-regulated by angiogenesis factors: A potential method for objective assessment of tumor angiogenesis. Int. J. Cancer 2000, 85, 281-288. [CrossRef]

55. Bradford, M.M. A rapid and sensitive method for the quantitation of microgram quantities of protein utilizing the principle of protein-dye binding. Anal. Biochem. 1976, 72, 248-254. [CrossRef]

56. Lee, H.B.; Blaufox, M.D. Blood volume in the rat. J. Nucl. Med. 1985, 26, 72-76. [PubMed]

(C) 2019 by the authors. Licensee MDPI, Basel, Switzerland. This article is an open access article distributed under the terms and conditions of the Creative Commons Attribution (CC BY) license (http:/ / creativecommons.org/licenses/by/4.0/). 